\title{
Population structures and seasons affected flowering, pollination and reproductive outputs of sandalwood in Gunung Sewu, Java, Indonesia
}

\author{
YENI W.N. RATNANINGRUM ${ }^{1, \vartheta}$, SAPTO INDRIOKO ${ }^{2, \bullet \vartheta}$, ENY FARIDAH $^{3}$, ATUS SYAHBUDIN $^{4}$ \\ ${ }^{1}$ Laboratory of Forest Seed Science and Technology, Faculty of Forestry, Universitas Gadjah Mada. Bulaksumur, Sleman 55281, Yogyakarta, Indonesia. \\ ’email: yeni.wnr@ugm.ac.id; yeniratnaningrum@gmail.ac.id \\ ${ }^{2}$ Laboratory of Forest Genetics and Tree Improvement, Faculty of Forestry, Universitas Gadjah Mada. Bulaksumur, Sleman 55281, Yogyakarta, \\ Indonesia." "email: sindrioko@ugm.ac.id \\ ${ }^{3}$ Laboratory of Plant Physiology, Faculty of Forestry, Universitas Gadjah Mada. Bulaksumur, Sleman 55281, Yogyakarta, Indonesia \\ ${ }^{4}$ Laboratory of Dendrology and Ethnobotany, Faculty of Forestry, Universitas Gadjah Mada. Bulaksumur, Sleman 55281, Yogyakarta, Indonesia
}

Manuscript received: 6 June 2017. Revision accepted: 25 January 2018.

\begin{abstract}
Ratnaningrum YWN, Indrioko S, Faridah E, Syahbudin A. 2018. Population structures and seasons affected flowering, pollination and reproductive outputs of sandalwood in Gunung Sewu, Java, Indonesia. Nusantara Bioscience 10: 12-26. Sandalwood was the origin to the south-eastern islands of Indonesia, but is recently occurred as new landraces in Gunung Sewu Geopark, Java, Indonesia. This study compared flowering and pollination, and their effect on reproductive outputs, among sandalwood populations in Gunung Sewu, during the dry and rainy season of 2016 flowering period. Flowering and pollination rate differed significantly between seasons but were similar among sites. Oppositely, reproductive outputs differed significantly among sites, but were similar between seasons. The rainy season produced more flowers and pollination. Pollination was less correlated to flowers abundance, but more affected by population size. The higher and cooler population visited more by Dipterans (31.8\% to 32.6\%) and Hymenopterans (28.2\% to $30 \%)$, while the warmer, lower sites dominated by Lepidopterans (37.2\% to $43 \%)$ and Dipterans (32.9\% to $38.2 \%)$. Higher population received fewer visits, but more visitors diversity (28 families). In contrast, lower sites received more visits, but with less diversity (20 families). Most insect families were considered "Rare" and "Occasional". However, pooled altogether, the whole families of Lepidopterans and Dipterans considered "Frequent" and "Effective". The Hymenopterans considered "Frequent" and "Effective" at Nglanggeran and Wanagama. The Cicadellidae of Coleopterans, along with arachnids and grasshoppers, were considered robbers. All of the agents were diurnal. However, the time of activity was varied. Rainy season gained more flowers and visits, but in contrast, resulted in fewer fruits at all sites. Both flowers abundance and pollination were negatively correlated to the reproductive parameters. Populations might gain more flowers and visits, but the reproductive outputs were significantly lower. Particularly in the clonalized and lower heterozygosity populations, more flowers increased geitonogamy which may lead to inbreeding depression.
\end{abstract}

Keywords: Flowering, pollination events, population structures, reproductive outputs, Santalum album

\section{INTRODUCTION}

Flowering plants have evolved, developed and specialized in response to the wide variety of pollen vectors which could serve for pollen transfer. Each flower parts have a specific role in the pollination process, and therefore, the morphology of these parts, and of the flower as a whole, may reveal much about breeding systems and pollination events (Barrett 2011; Wilmer 2012). The blossom architecture including the spatial arrangement of sexual organs, accessibility of rewards, and the floral size and structure, all influence the plant-pollinator interaction. Since visiting agents show a corresponding variation in their size, sensory perception, feeding behavior and energy requirements, a certain general relationship exists between blossom architecture and pollinator type (Etcheverry et al. 2008; Barrett 2011).

The components of floral traits, such as plant size, plant age, floral structures and sexual organs arrangement (Arroyo et al. 2006; Herlihy and Eckert 2007; Etcheverry et al. 2008; Ortigosa and Gomez 2009; Barrett 2011; Tamla et al. 2012; da Cruz et al. 2014), altogether arrange floral display within population. Differences on floral display might be resulted in different pollinators and pollination behavior, which affect mating systems and genetic diversity (Herlihy and Eckert 2007; Arroyo et al. 2006; Barrett 2011; Kartikawati et al. 2013), reproductive outputs (Tsaliki and Diekmann 2011; Nadia and Machado 2014) and population fitness (Provan et al. 2008; Weber and Kolb 2013). Furthermore, they might exhibit different response to the environmental triggers (Richardson et al. 2013). Differences in reproductive outputs in responses to the environmental triggers, therefore, may reflect differences in the component of floral display and the resulting reproductive processes (Etcheverry et al. 2008; Wilmer 2012; Agullo et al. 2015).

The Outer Arc of Banda Islands, now is the southeastern parts of Indonesian archipelagos, has been believed as the origin of sandalwood worldwide. Sandalwood in India and Australia were even considered as the result of gene introduction from Timor Island, Indonesia, hundred years ago (Rao et al. 2007). Santalum album Linn (Santalaceae), hereinafter referred to sandalwood, produce heartwood containing 1.5 to $5 \%$ of $\beta$-santalol, a strong, specific fragrances of oil. Its heartwood is widely used for wood carving, art, religious and medicinal purposes. Its oil 
is the materials of cosmetics, perfumes, and aroma-therapy, and was considered containing anti-melanoma compounds (Rao et al. 2007; Dani et al. 2011; da Silva et al. 2016). However, significant genetic depletion was reported throughout the world, emphasized the forest fragmentation as the main factor responsible for sandalwood extinction (Warburton et al. 2000; Byrne et al. 2003; Bottin et al. 2007; Lhuillier et al. 2006; Rao et al. 2007; Dani et al. 2011; Herawan et al. 2014; Indrioko and Ratnaningrum 2015a,b; da Silva et al. 2016). In 1994, sandalwood was first listed as vulnerable on the IUCN Red List due to habitat degradation as the results of population size reduction. Since 2004, sandalwood was even considered Extinct in the Wild in most of its native in the south-eastern islands of Indonesia (Indrioko and Ratnaningrum 2015b). Considering this, the vulnerable status might be stepped up to Endangered, Critically Endangered or even Extinct in the Wild, and therefore the conservation status supposed to be re-evaluated (IUCN 2009).

In spite of significant degradation in their origin in the South-eastern islands of Indonesia, new landraces of sandalwood extended along geographical gradients in Gunung Sewu Geopark (Office of Forestry Yogyakarta Province 2015), a $1300 \mathrm{~km}^{2}$ mountainous limestone zones in the central part of Java island (Haryono and Suratman 2010). Most of these landraces are naturally isolated due to the restriction of the uplift and downlift formation of various landscape types. Some of them are also fragmented due to various scenarios which are involved in geographical, evolutionary and disturbance histories. The low genetic diversity and reproductive failure of sandals in some of the fragmented populations is an indication that the mating systems and reproductive processes of this selfincompatible species have already been disrupted (Indrioko and Ratnaningrum 2015a,b; Ratnaningrum and Indrioko 2014, 2015). Many studies in sandals revealed that differences in population structures affected flowering and pollination events, thus altered the mating systems and reproductive outputs; as reported for $S$. album in India (Sindhu-Vereendra and Anantha-Padmanabha 1996; Rughkla et al. 2006), S. album in Java Island, Indonesia (Ratnaningrum and Indrioko 2014, 2015) and $S$. lanceolatum in Victoria Australia (Warburton et al. 2000).

Considering a rapid degradation in their origin, thus the occurrence of these new landraces sounds promising for any of reintroduction and rehabilitation efforts. This study compared flowering, pollination and reproductive parameters among five sandalwood populations along environmental gradients in Gunung Sewu, in the dry and rainy season of 2016 flowering periods. The flowering traits, floral visitors diversity, visitation rate and pollination behavior were observed in both two seasons. The reproductive outputs, seed viability, and seedling survival at three months old were examined. The correlation between floral traits, pollination, and reproductive parameters was then analyzed.

\section{MATERIALS AND METHODS}

\section{Characteristics of study sites}

Gunung Sewu $\left(7^{0} 50^{\prime} \mathrm{S}\right.$ to $\left.100^{\circ} 60^{\prime} \mathrm{E}\right)$ is the mountainous limestone zones in Java Island, the central parts of Indonesian archipelagos, which grew through dissolution when the limestone was uplifted from the seabed about 1.8 million years ago. Recently Gunung Sewu areas stretched $85 \mathrm{~km}$ west-east covers three Geo Areas of Gunungkidul (Yogyakarta), Wonogiri (Central Java), and Pacitan (East Java), with approximate area of $1300 \mathrm{~km}^{2}$ (Haryono and Suratman 2010). Based on this geographical formation history, Gunungkidul Geo Area is now derived into three zones: (i) Northern Zone, consisted of the Batur Agung Highland at $300 \mathrm{~m}$ to $800 \mathrm{~m}$ asl, and the lowland of Sambipitu formation at $200 \mathrm{~m}$ to $300 \mathrm{~m}$ asl; (ii) Middle Zone, the lowland basin of Ledok Wonosari at $150 \mathrm{~m}$ to $300 \mathrm{~m}$ asl; and (iii) Southern Zone, the Pegunungan Seribu Karst areas at $0 \mathrm{~m}$ to $200 \mathrm{~m}$ above sea level (asl). Gunung Sewu possesses two seasons. The rainy season occurs during October to March and the dry season took place from April to September. As it is adjacent to the Indian Ocean, Gunung Sewu areas are having two types of climate -- $A w$, the semi-arid to arid type that is characterized by a long drought; and $\mathrm{Am}$ which is representing an intermediate condition between the tropical and sub-tropical climate (Haryono and Suratman 2010).

Gunung Sewu consisted of more than ten sandalwood landraces in the form of both planted and naturally regenerated stands, which occurred at various types of landscapes along the geographical zones. Several ex situ conservation areas, which were separated only by $2 \mathrm{~km}$ to less than $8 \mathrm{~km}$, were established in the Middle Zone since 1967. These conservation areas, totally comprised more than $30 \mathrm{Ha}$ of width, consisted of more than 40 provenances originated from Timor and Java islands. Landraces and conservation areas in this Middle Zone also share the same Oya River (Office of Forestry Yogyakarta Province 2015; Figure 1). This study was conducted only at five landraces in Gunung Sewu which were having clear history of establishment, naturally regenerated, able to reproduce sexually, and representing each of geographical zones: Nglanggeran mountain in the highland of Northern Zone, Bejiharjo in the lowland of Northern Zone, Bleberan basin in the Middle Zone, the ex-situ conservation area GSM3-Wanagama in the Middle Zone, and the karst area Petir in the Southern Zone. Each of Gunung Sewu Zones is separated by 25 to $40 \mathrm{~km}$, but landraces within the zone are separated by less than $10 \mathrm{~km}$, with the exception for Bejiharjo which is separated by more than $30 \mathrm{~km}$ away from any other landraces. These sites are at different altitude, experienced different climatic regimes and having clear ecological differences.

\section{Study species}

Sandalwood is a long-lived, yearly flowering perennial of the semi-arid and tropical region throughout southeastern and middle parts of Indonesia. It is a shrub attaining a height of about $12 \mathrm{~m}$ and a girth of 10 to $30 \mathrm{~cm}$ (Rao et al. 2007; da Silva et al. 2016), mainly reproduced by root 
suckers, the vegetatively propagated sproutings of the horizontal roots (Warburton et al. 2000; Lhuillier et al. 2006; Dani et al. 2011; Herawan et al. 2014; da Silva et al. 2016). It is entomophilous and often produced abundant flowers (Warburton et al. 2000; Ratnaningrum and Indrioko 2014; Tamla et al. 2012). Flowers arranged in inflorescences consisted of 20 to 40 small-red single flowers. Sandalwood in Indonesia flowered annually twice a year, at the beginning of the dry season (May to September) and rainy season (November to March), with 4 to 5 months flowering period (Ratnaningrum and Indrioko 2015, 2016). The previous study showed evidence of dichogamy, pollen mature two days before stigma receptivity (Ratnaningrum and Indrioko 2014). Studies on sandals' mating systems have indicated highly outcrossing rate and self-incompatibility (Ratnaningrum and Indrioko 2014; Rughkla et al. 2006; Rao et al. 2007; Dani et al. 2011; Tamla et al. 2012; Indrioko and Ratnaningrum 2015; da Silva et al. 2016). However, partially self-compatibility has also been reported for $S$. accuminatum (Warburton et al. 2000) and S. album (Sindhu-Vereendra and AnanthaPadmanabha 1996; Ratnaningrum and Indrioko 2014), particularly under isolated condition. Despite its abundant flowers, the fruit production is very low, ranging from less than $5 \%$ in small populations (Sindhu-Vereendra and Anantha-Padmanabha 1996; Warburton et al. 2000; Byrne et al. 2003; Indrioko and Ratnaningrum 2015b) to about $20 \%$ in the bigger and wider genetic bases' populations (Ratnaningrum and Indrioko 2015, 2016; da Silva et al. 2016).

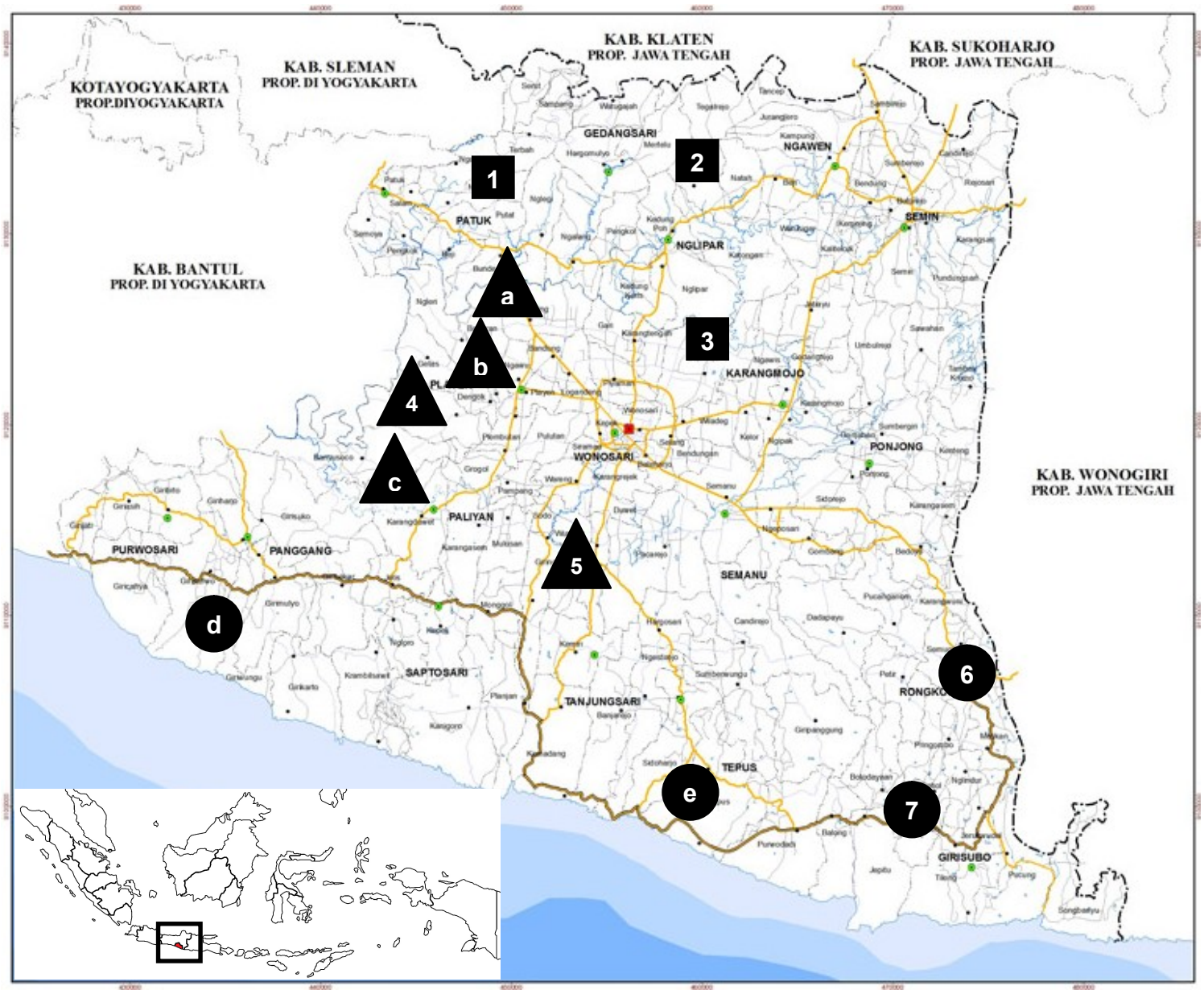

Figure 1. Study sites: sandalwood landraces in the Gunung Sewu Geopark, Java island. The Gunung Sewu groups: the first group (Northern Zone): Nglanggeran (1), Sriten (2) and Bejiharjo (3); the second group (Middle Zone): Bunder (a), Wanagama (b), Banyusoco (c), Bleberan (4), and Mulo (5); and the third group (Southern Zone): Petir-Semugih (6), Botodayakan (7), Panggang (d) and Tepus (e) landraces, respectively. The Arabic numbers represent natural landraces, while the alphabetic fonts represent ex situ conservation and/or plantation areas, respectively. Within each Gunung Sewu zone, sandalwood landraces are marked by squares (Northern Zone), triangles (Middle Zone) and circles (Southern Zone) shapes, respectively. The study was conducted at Nglanggeran (1), Bejiharjo (3), Bleberan (4), Wanagama (b) and Petir-Semugih (6) 


\section{Procedures}

\section{Pollinators and pollination observation}

Observation carried out over 120 hours at each of population, spread across two flowering periods in the rainy season of 2015's and dry season of 2016's. An exception was made for GSM3-Wanagama, at which the observation was only conducted in the rainy season of 2015's due to the loss of research materials. Pollinators activity was quantified on each of population in every season, whereby independent observers simultaneously monitored visitation at five points, with two flowering trees per point (total $\mathrm{N}=5$ points $\mathrm{x} 2$ flowering trees $\mathrm{x} 5$ populations $=50$ trees in a total five populations per season), for periods of 12 hours per day (started from 05:00 am to 05:00 pm), over a total of five days of peak flowering period, according to methods arranged by Machado and Sazima (2008) and Borges et al. (2009). The observation interval at each of population varied from 48 to 60 hours per flowering period, there being fewer than 60 hours in the highland site on account of heavy rain at this higher elevation.

Total number of single flowers referred to the sum of all flowers produced by the ten sampled trees at each of site. The type and abundance of flower visitors were recorded. Visitation rate, referred to the number of visits per given period (da Cruz et al. 2014), was measured for each type of flower visitors. The flower visitors were classified according to the visitation frequency, which is very frequent ( $\mathrm{VF}$, present for more than $50 \%$ of total visits), frequent (F, $20 \%$ to $50 \%$ of total visits), or rare (R, less than $20 \%$ of total visits) (Machado and Sazima 2008). Visiting behavior were then classified as effective pollinators (E, when they made frequent visits and constantly contacted the floral sexual organs while collecting rewards), occasional pollinators $(\mathrm{O}$, when they contacted floral sexual organs but only made rare visits), or thieves/robbers ( $\mathrm{T}$, when they took advantages of rewards without made any contacts on floral sexual organs) (Borges et al. 2009). To observe plant-pollinator interactions, a daily observation was made on stigmatic contact, pollen load, interplant movement, and feeding behavior. The visiting insects were captured for pollen load observation, and dry mounted for identification in the Entomological Laboratory, Universitas Gadjah Mada.

\section{The reproductive parameters measurements}

To measure reproductive parameters (pollination effectiveness, $P E$ and reproductive success, $R S$ ) in open pollination, the flowers, fertilized flowers (young fruits) and mature fruits of the ten sampled trees per populations were counted (total $\mathrm{N}=50$ trees in a total five populations per season). The value of $\mathrm{PE}$ and RS were then calculated following Owens et al. (2001). Pollination Effectiveness $(P E)$, represents the ability of reproductive organs to pollinate, fertilize and produce a young fruit, was measured by dividing the number of fertilized flower to flower. Reproductive success $(R S)$, corresponds to the ability of reproductive organs to form mature seeds, was measured following the formula, $\mathrm{RS}=$ (fruit/flower) $\mathrm{x}$ (seed/ovule). As the fruit of sandalwood is a single-seeded, in which each of fruit is derived from ovary bearing only one ovule, therefore the seed/ovule equal to 1 .

To determine seed viability, all mature seeds were collected from the ten sampled trees per population per season. Seeds were soaked in the water for 24 hours, manually extracted, air dried under room temperature, and sowed in sterile sands media. Seed viability is the number of germinated seeds divided by the total of sowed seeds. Seedling survival is the number of survived seedling at 3 months old divided by the total of germinated seeds.

\section{Statistical analysis}

Test of analysis of variance (ANOVA) was performed to determine differences in flowers abundance, pollination rate, pollination effectiveness $(\%)$, reproductive success $(\%)$, seed viability (\%) and seedling survival (\%), among sites and between seasons. To determine the relationship between parameters, the data of both seasons were pooled. Multiple linear regressions based on flowers abundance and pollination rate correlated both dependent variables with the predictor variables of pollination effectiveness $(\%)$, reproductive success $(\%)$, seed viability $(\%)$ and seedling survival (\%). Some of the variables were subjected to logarithmic transformation to obtain normal data distributions. For the multiple regression analysis, a backward stepwise procedure was applied, with the final model including only variables with a significant $(p<0.05)$ effect on the dependent variable. All statistical analyses were carried out with SPSS (Version 16.0, SPSS Inc.).

\section{RESULTS AND DISCUSSIONS}

\section{Flower abundance, pollinators and pollination activity}

Pollinator observation was made on five landraces in Gunung Sewu: Nglanggeran (hereinafter referred to GSN1Nglanggeran), GSN3-Bejiharjo, GSM1-Bleberan, GSM3Wanagama, and GSS1-Petir. In over a total of 540 hours of field observations made during two flowering periods in the rainy season of 2015 and dry season of 2016, the number of visits totaled 2063 for a sum total of 238,155 single flowers (five populations, two seasons, 10 flowering trees each) (Table 1).

\section{Flower abundance and pollinators visitation rate}

ANOVA showed differences in the flower abundance and pollination rate between the dry and rainy season, but none of the reproductive outputs differed between both seasons. In contrast, the flower abundance and pollination rate were similar among five populations observed. However, the reproductive outputs differed significantly among sites (Table 1). The flowers production and visitation rate were higher in the rainy season at all sites. The total number of flowers, which is referred to the sum of all flowers produced by the ten trees sampled, ranged from 20,000 to 59,000 single flowers in the rainy season, and from 6,000 to 21,000 single flowers in the dry season, respectively, depended on the differences on flowers and inflorescences production per tree. Total pollinator visits ranged from 206 to 328 in the rainy season, and from 123 
to 210 in the dry season, respectively, in line with the fluctuation of rewards abundance.

As predicted, GSM3-Wanagama and GSN3-Bejiharjo, which produced abundant flowers in the ten trees observed (more than 25,000 single flowers per ten trees), received larger visits (328 visits and 260 visits per 5 days, respectively). GSM1-Bleberan received only 164 visits, probably due to the less of reward availability (only 17,000 single flowers per ten trees). GSS1-Petir produced the lowest flower abundance (only 13,000 single flowers) but received more visits (253 visits). In contrast, the highland population GSN1-Nglanggeran produced largest flowers abundance $(40,000$ single flowers per ten trees) but was having fewer visits (only 189 visits).

A variation on visitor abundance and diversity may be attributed to the variation in rewards availability and environmental condition among sites and between seasons (Figure 2a). The higher population, which experienced cooler and wetter $A m$ climatic type, visited more by Dipterans (ranged from $31.8 \%$ to $32.6 \%$ out of total visitation in this site) and Hymenopterans (ranged from $28.2 \%$ to $30 \%$ ). In the warmer and lower sites under $A w$ climatic type, visitation was dominated more by Lepidopterans (ranged from $37.2 \%$ to $43 \%$ ) and Dipterans (ranged from $32.9 \%$ to $38.2 \%$ ). The lower sites experienced fewer visits by Coleopterans (ranged from $1.9 \%$ to $5.8 \%$ ) and Hemipterans (ranged from $3.4 \%$ to $4.3 \%$ ). Both orders made more visits to the highland site $(8.3 \%$ for Coleopterans and $7.9 \%$ for Hemipterans, respectively). At all sites, visitors abundance was higher in the rainy season when more rewards were available.

\section{Visitors diversity}

As well as their abundance, visitors diversity also varied with altitude. In general, the higher population received fewer visits, but the visitors were higher in diversity (28 families of insects). In contrast, the visitation rate was higher in the lower sites, but with lower diversity (only 20 families of insects). The Byturidae, Tenebrionidae, and Coccinellidae (Coleopterans), Pipunculidae and Stratiomydae (Dipterans), Scoliidae and Megachilidae (Hymenopterans), and Phyrrocidae, Scutelleridae, and Cicadellidae (Hemipterans), were observed only in the highland population and not at the lowland ones. In contrary, the Platasipidae (Hemipterans) were found only at the lowland sites. The Cossidae family, which belongs to the moths' group of Lepidopterans, was appeared only in the lowland sites during the rainy season but was absent in the dry season (Figure 2b, c, d, e, f).

Table 1. Flowers abundance, pollination rate, and reproductive outputs in the five of sandalwood populations between two seasons in Gunung Sewu, Java, Indonesia

\begin{tabular}{|c|c|c|c|c|c|c|}
\hline $\begin{array}{c}\text { Populations and } \\
\text { seasons }\end{array}$ & $\begin{array}{c}\text { Flowers } \\
\text { abundance }\end{array}$ & $\begin{array}{c}\text { Pollination rate } \\
\text { (individuals/5 } \\
\text { days) }\end{array}$ & $\begin{array}{c}\text { Pollination } \\
\text { effectiveness (\%) }\end{array}$ & $\begin{array}{l}\text { Reproductive } \\
\text { success (\%) }\end{array}$ & $\begin{array}{c}\text { Seed } \\
\text { viability }(\%)\end{array}$ & $\begin{array}{c}\text { Seedling } \\
\text { survival }(\%)\end{array}$ \\
\hline \multicolumn{7}{|l|}{ Among populations } \\
\hline \multicolumn{7}{|l|}{ Nglanggeran } \\
\hline Rainy season & 59321.60 & 223 & 4.62 & 2.30 & 15.37 & 31.43 \\
\hline Dry season & 21045.00 & 156 & 10.31 & 7.53 & 44.70 & 66.38 \\
\hline Average & 40183.30 & 189.50 & 7.47 & 4.91 & 30.04 & 48.91 \\
\hline \multicolumn{7}{|l|}{ Bejiharjo } \\
\hline Rainy season & 37259.20 & 310 & 0.91 & 0.25 & 0.00 & 0.00 \\
\hline Dry season & 13905.65 & 210 & 3.89 & 1.74 & 0.83 & 0.00 \\
\hline Average & 25582.43 & 260.00 & 2.40 & 1.00 & 0.41 & 0.00 \\
\hline \multicolumn{7}{|l|}{ Bleberan } \\
\hline Rainy season & 28007.00 & 206 & 12.37 & 4.90 & 35.30 & 53.31 \\
\hline Dry season & 7243.04 & 123 & 21.72 & 11.28 & 78.82 & 90.53 \\
\hline Average & 17625.02 & 164.50 & 17.04 & 8.09 & 57.06 & 71.92 \\
\hline \multicolumn{7}{|l|}{ Petir } \\
\hline Rainy season & 20176.00 & 302 & 13.45 & 6.36 & 39.49 & 8.09 \\
\hline Dry season & 6609.00 & 205 & 22.23 & 13.36 & 79.50 & 11.82 \\
\hline Average & 13392.50 & 253.50 & 17.84 & 9.86 & 59.49 & 9.96 \\
\hline \multicolumn{7}{|l|}{ Wanagama } \\
\hline Rainy season & 25580.20 & 328 & 18.26 & 8.51 & 68.93 & 80.00 \\
\hline Dry season & NA & NA & NA & NA & NA & NA \\
\hline Average & 25580.20 & 328 & 18.26 & 8.51 & 68.93 & 80.00 \\
\hline F stat. & 0.798 & 2.692 & $5.095^{*}$ & 2.124 & $3.586^{*}$ & $9.876^{*}$ \\
\hline$P$ value & 0.575 & 0.153 & $0.052 *$ & 0.215 & $0.057^{*}$ & $0.014^{*}$ \\
\hline \multicolumn{7}{|l|}{ Between seasons } \\
\hline Rainy season & 34068.80 & 273.80 & 9.92 & 4.46 & 31.82 & 34.56 \\
\hline Dry season & 12200.67 & 173.50 & 14.54 & 8.48 & 50.96 & 42.18 \\
\hline F stat. & $6.846^{*}$ & $8.993^{*}$ & 0.754 & 2.078 & 0.829 & 0.091 \\
\hline$P$ value & $0.035^{*}$ & $0.020^{*}$ & 0.414 & 0.193 & 0.393 & 0.772 \\
\hline
\end{tabular}

Note: $F$ ratios and $P$ values resulted from test of analysis of variance (ANOVA, LSD test) performed among parameters within populations and within seasons. Asterisked values $\left(^{*}\right)$ indicated significant differences at $\mathrm{P}<0.05$. NA $=$ Not Assessed; the materials were missing 


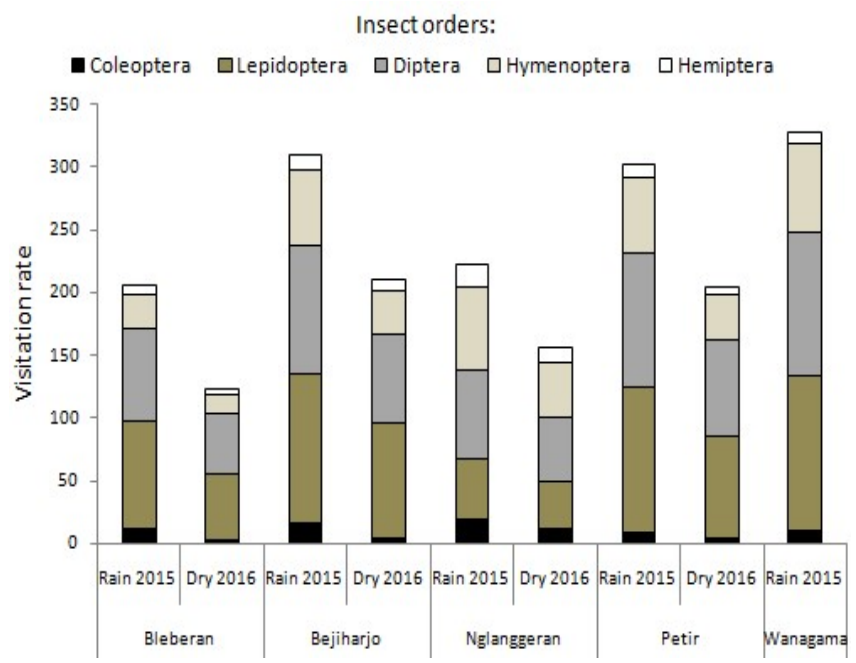

A

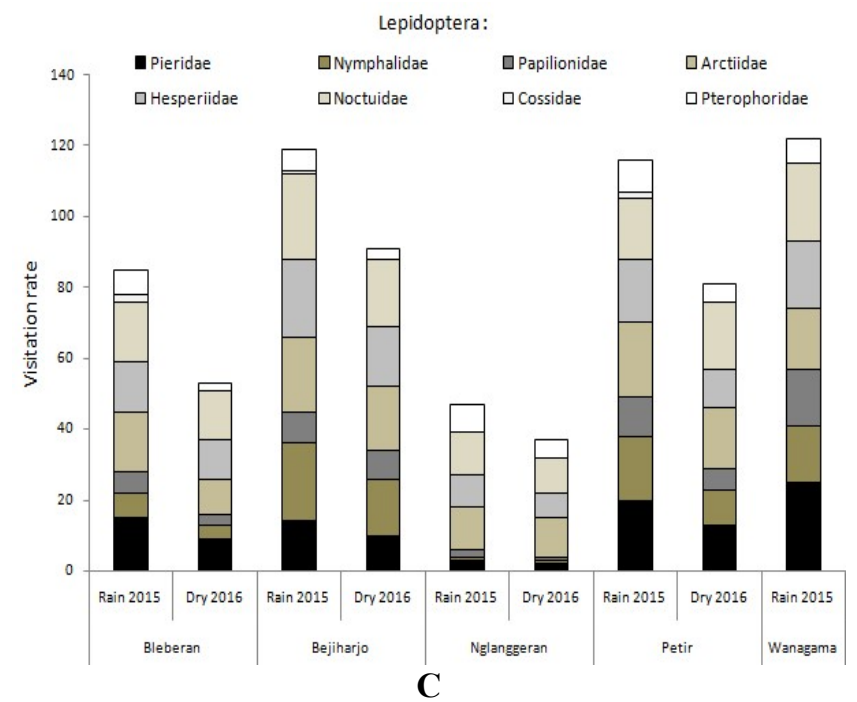

C

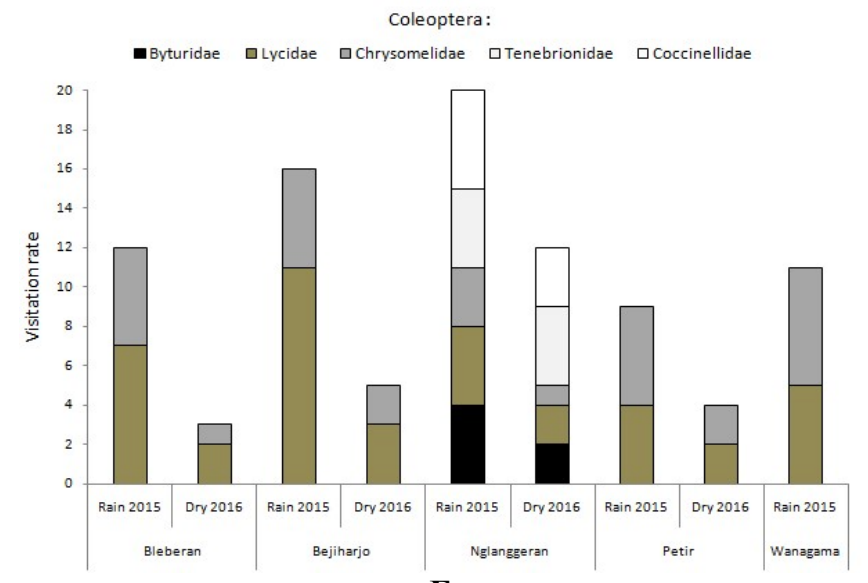

$\mathbf{E}$

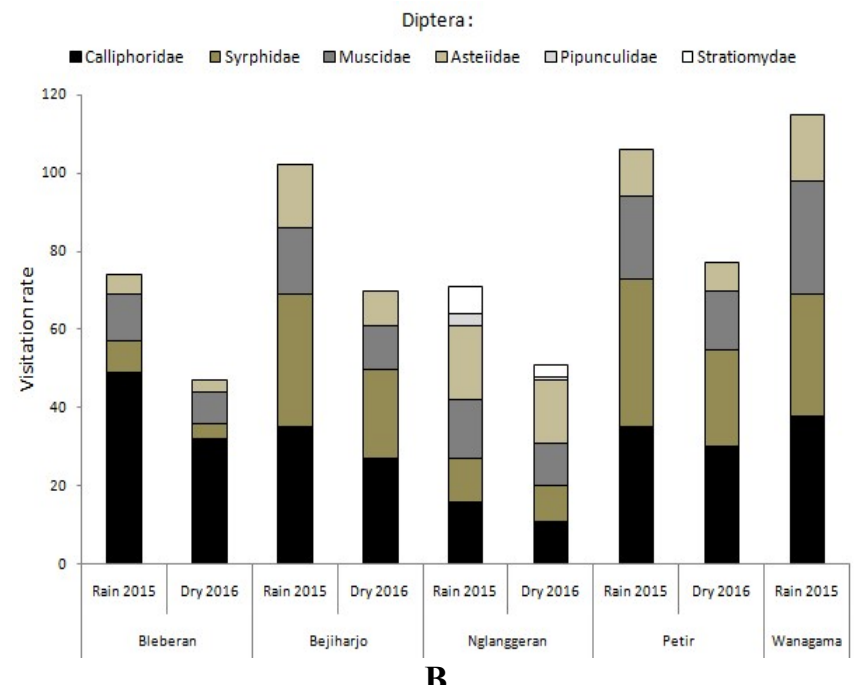

B
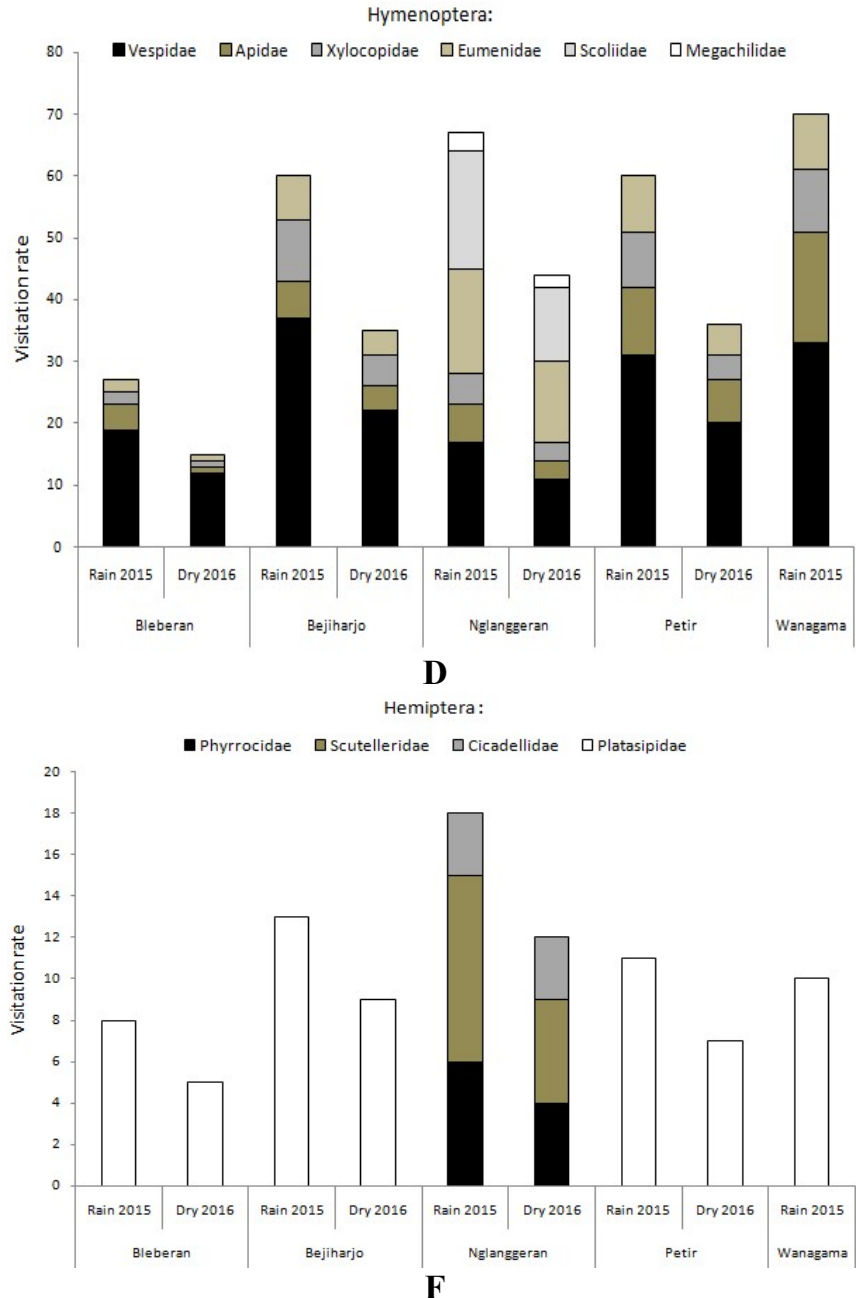

Figure 2. The visitors abundance at the Order level (A), and their diversity at the family levels within the Order of Dipterans (B), Lepidopterans (C), Hymenopterans (D), Coleopterans (E) and Hemipterans (F), in five sandalwood landraces in Gunung Sewu, Java, Indonesia

\section{The frequency and efficiency of visitors}

The frequency and efficiency of visitors vary with the structures, sizes, abundance and feeding behavior, since these traits may affect stigmatic contact, pollen load and interplant movement, which in turn ensured pollen transfers within and among populations. Regarding this, the flower visitors were classified by the visitation frequency, which is representing the percentage of visits to the total visitation, and the efficiency of pollination, which is according to their entire characteristics that contribute to the pollen transfer (Table 2). 
Table 2. The percentage of visitation (\%), visitation frequency (VF/F/R) and the visitors efficiency (E/O/T) on sandalwood flowers among five populations in Gunung Sewu, Java, Indonesia

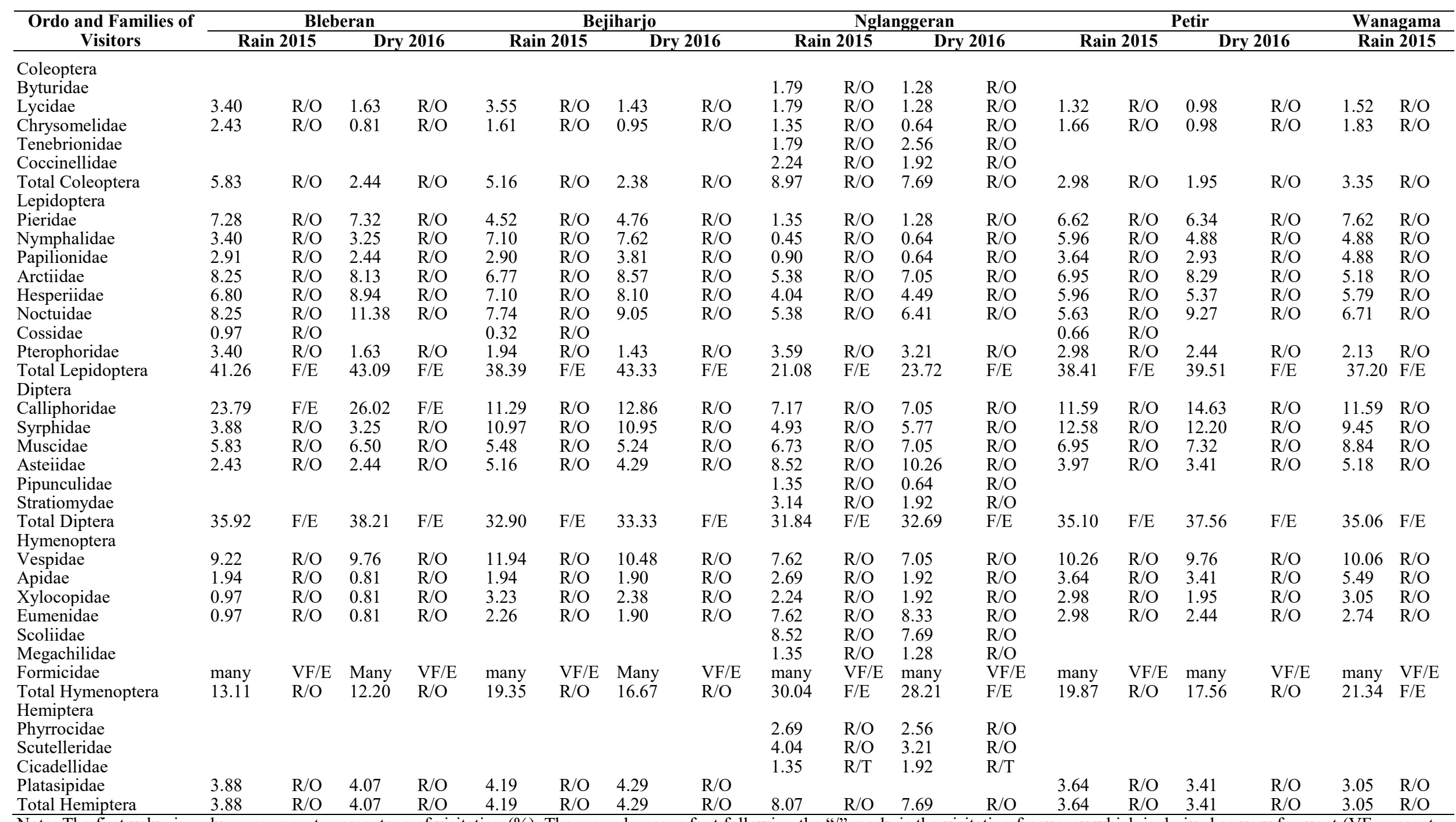

Note: The first value in column represents percentage of visitation (\%). The second ones, a font following the "/" mark, is the visitation frequency which is derived as very frequent (VF, present for more than $50 \%$ of total visits), frequent ( $20 \%$ to $50 \%$ of total visits), or rare (R, less than $20 \%$ of total visits). The last font represents the visitors efficiency which is classified as effective pollinators (E, when they made frequent visits and constantly contacted the floral sexual organs while collecting rewards), occasional pollinators (O, when they contacted floral sexual organs but only made rare visits), or thieves/robbers ( $\mathrm{T}$, when they took advantages of rewards without made any contacts on floral sexual organs) 
Most of insect families were considered "rare" and "occasional" (R,O) as they only made infrequent visits and/or less contact with floral organs. However, in unify of the whole families, the order of Lepidopterans and Dipterans considered "frequent" and "effective" at all sites, since they were present in frequent numbers (ranged from $21 \%$ to $43 \%$ for Lepidopterans and $31.8 \%$ to $35.9 \%$ for Dipterans, respectively), and their feeding behavior ensure the intensive contact to floral sexual organs. The Hymenopterans considered "frequent" and "effective" only at Nglanggeran, probably due to the suitable highland environment and resource availability. This order was also found to be "frequent" and "effective" in Wanagama, a lower site which produced more flowers. The Cicadellidae of Hemipterans, along with other taxa such as arachnids and grasshoppers, were considered thieves as they took advantages of rewards without made any contacts on floral sexual organs. The arachnids and grasshoppers were observed to cause floral damages while seeking for rewards.

All of agents were considered diurnal visitor. However, the time range of activity was varied. Moths found in the earliest morning at 05:00 am and tended to have longer interval of activity, since their presence was still recorded until 04:00 pm. Bees and flies observed 1 hour later at 07:00 am to 02:00 pm. Wasps, beetles, and flies found later at 08:00 am and finished their activity at 03:00 pm. The latest was butterflies which have just found after 09:00 am and disappeared at 03:00 pm. Whilst, ants presence were observed within the same tree the whole day through. All of agent activities peaked before daytime.

The reproductive outputs (pollination effectiveness, reproductive success, seed viability and seedling survival)

Reproductive outputs differed significantly among sites but were similar between seasons (Figure 3). A variation on flowers abundance and pollination rate may contribute to the differences in reproductive outputs among sites. As predicted, the GSM3-Wanagama which has more flowers and visitors produced highest reproductive outputs $(18.26 \%$ PE, $8.5 \%$ RS, $68.9 \%$ seed viability, $80 \%$ seedling survival). GSM1-Bleberan, which produced fewer flowers and gained fewer visits, surprisingly achieved relatively high reproductive outputs $(17.04 \%$ PE, $8.1 \%$ RS, $57.1 \%$ seed viability, $71.9 \%$ seedling survival). The highland population GSN1-Nglanggeran, which has most abundant flowers but received fewer visits, produced a moderate level of reproductive outputs $(7.47 \%$ PE, $4.9 \%$ RS, 30\% seed viability, $48.9 \%$ seedling survival).

The two of clonalized populations, GSS1-Petir and GSN3-Bejiharjo, gained very low reproductive outputs. In both heavily-clonalized populations, mating system is dominated by selfing, and therefore inbreeding depression may occur at the early or later reproductive phase. In GSS1-Petir which produced fewer flowers but received more visits, the early phase of reproductive was achieving relatively high results. However, it extremely declined at the later phase $(17.8 \% \mathrm{PE}, 9.8 \% \mathrm{RS}, 59.5 \%$ seed viability, $9.9 \%$ seedling survival). The reproductive failure was more apparent in GSN3-Bejiharjo which flowered abundantly and visited by more pollinators, but produced very low reproductive outputs at any stages of developments (only $2.4 \%$ PE, $1 \%$ RS, $0.4 \%$ seed viability, $0 \%$ seedling survival). All populations produced fewer flowers and visited by fewer pollinators in dry season. However, it resulted in more seed sets. The rainy season produced more flowers and gained more visits, but in contrast, resulted in fewer fruits due to the high abortion of flowers and fruits.

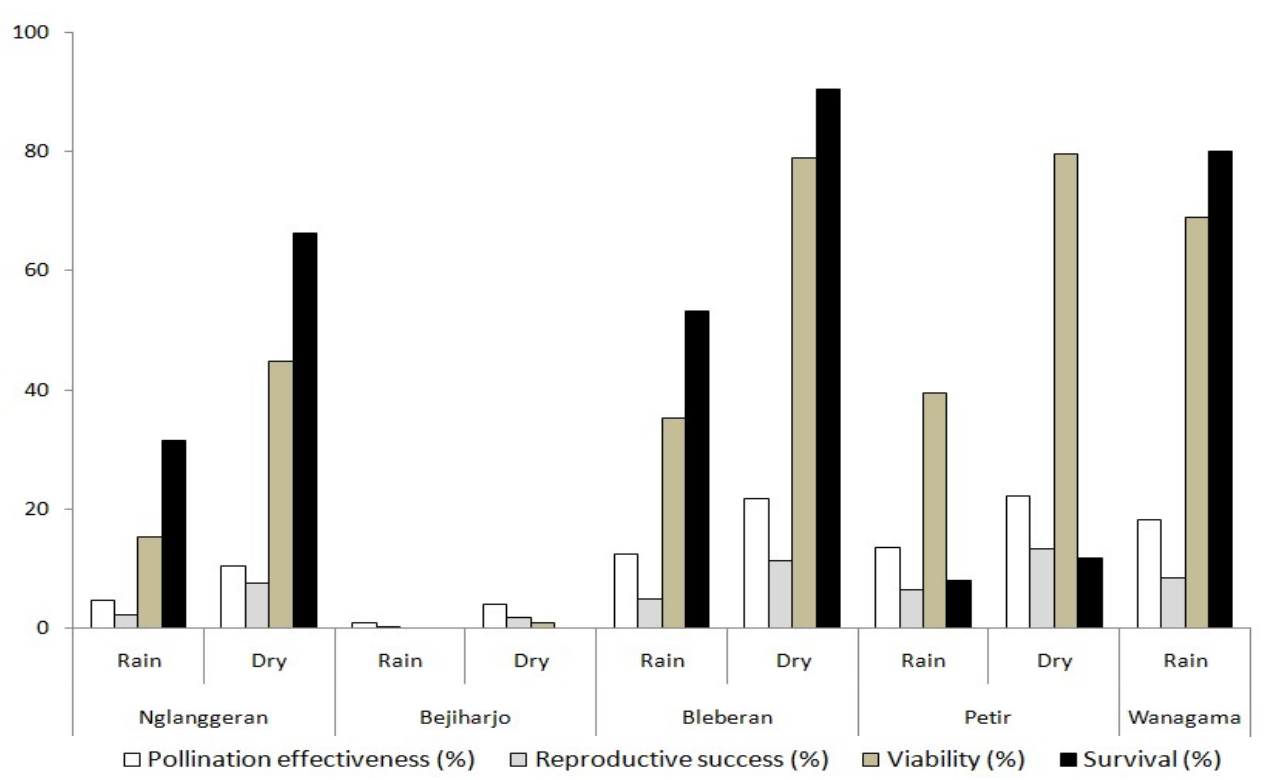

Figure 3. Comparison mean ( $(+$ S.E.) of pollination effectiveness (PE, \%), reproductive success (RS, \%), seed viability (\%) and seedling survival at 3 months old (\%) under open pollination in five sandalwood populations in Gunung Sewu, Java, Indonesia 
Table 3. Results of stepwise multiple regressions correlated the flowers abundance to the pollinators visitation rate; and correlated the flowers abundance and pollinators visitation rate to the independent variables of reproductive outputs, in the three variants of sandalwood among four populations in Gunung Sewu, Java, Indonesia

\begin{tabular}{|c|c|c|c|c|c|}
\hline \multirow[b]{2}{*}{ Dependent variable } & \multicolumn{5}{|c|}{ Independent variables } \\
\hline & $\begin{array}{c}\text { Pollinators } \\
\text { visitation rate }\end{array}$ & $\begin{array}{c}\text { Pollination } \\
\text { effectiveness (\%) }\end{array}$ & $\begin{array}{c}\text { Reproductive } \\
\text { success }(\%)\end{array}$ & $\begin{array}{c}\text { Seed viability } \\
(\%)\end{array}$ & $\begin{array}{c}\text { Seedling survival } \\
(\%)\end{array}$ \\
\hline Population size & $0.098(+) ; 0.341$ & & & & \\
\hline Flowers abundance & $0.354(+) ; 0.123$ & $0.053(-) ; 0.411^{*}$ & $0.049(-) ; 0.446^{*}$ & $0.107(-) ; 0.328$ & $0.733(-) ; 0.017$ \\
\hline Pollinators visitation rate & & $0.503(-) ; 0.066$ & $0.334(-) ; 0.133$ & $0.473(-) ; 0.076$ & $0.306(-) ; 0.148$ \\
\hline
\end{tabular}

Note: The first value in the table shows the $\mathrm{p}$ values and the direction of the relationship (in parenthesis), and the second value refers to the $\mathrm{R}^{2}$. Asterisked values indicated significant differences at $\mathrm{p}<0.05$

\section{The effects of floral and pollination traits on the reproductive outputs}

Pollinators visitation rate is less correlated to the flowers abundance but more affected by the proportion of flowering trees in populations. Flowers abundance strongly affected Pollination Effectiveness and Reproductive Success, but was less correlated to the seed viability and seedling survival. However, none of the reproductive parameters were affected by pollinators visitation rate. And surprisingly, both dependent variables, flowers abundance, and pollinators visitation rate, showed negative trend line in any of regression analysis correlating to the reproductive parameters. It implied that more flowers gained more visits, but resulted in the lower reproductive outputs (Table 3).

\section{Discussion}

Pollinators and pollination activity

Flowers abundance and pollinators visitation rate differed between seasons, but were similar among sites. More flowers and visits were gained in the rainy season at all sites. Visitation rate is less correlated to the individual flowers abundance, but more affected by the population size, with regard to the proportion of whole flowering trees in populations. As predicted, populations with fewer flowering trees received less visitor diversity and abundance. Many studies also reported similar findings in which pollination rate was decreased in the less flowered populations; as well as those observed in Genista spp. (Tsaliki and Diekmann 2011), Aquilegia canadensis (Herlihy and Eckert 2007), Vigna caracalla (Etcheverry et al. 2008) and Helianthemum caput-felis (Agullo et al. 2015).

The variation in visitor abundance and diversity may be due to the variation in rewards availability and environmental condition among sites and between seasons. The flowering period in this study varied with sites and season. At all sites, rainy season produced more flowers and gained more visits, but in contrast, resulted in fewer fruits due to the high abortion of flowers and fruits. Another study in tropical regions also revealed that the resources availability, with regard to water and nutrients, peaked during the rainy season. It was also a case with Heliconia sp in Brazilian tropical forest, which were influenced by two distinctive climatic types: a wet and a longer dry season; and therefore have different flowering period despite the restricted geographic range (da Cruz et al. 2014).

Weather is considered crucial in determining pollinator visitation rates and abundance, and the pollinators behavior may differ with the climatic regimes (Tsaliki and Diekmann 2011; Wilmer 2012; Richardson et al. 2013). In temperate regions, pollinators were less active when temperatures were high (Arroyo et al. 2006), or when days are very cold, cloudy or windy (Weber and Kolb 2013); but the opposite trends may occur with warmer and dryer sites (Tsaliki and Diekmann 2011; Agullo et al. 2015). Differences in flower longevity and abundance were mostly influenced by variation in environmental factors such as temperature (Tamla et al. 2012; Ratnaningrum and Indrioko 2015, 2016), and as reported in this study, were considered to be the main factor causing differences on pollinators diversity and visitation rate (Tsaliki and Diekmann 2011). Another study in Genista anglica in Bremen, Germany found that high pollinator visitation rates were associated with warm conditions, but the visit by Apis and Bombus decreased significantly when the temperature exceeded a certain level. On cloudy and windy days pollinators were also less abundant (Tsaliki and Diekmann 2011).

This study found no significant differences in visitation rate among sites. However, the visits tended to be lower at the higher altitude population. Many studies suggested that visitor composition, in term of their diversity and abundance, differed across the altitudinal gradients, and were related to the environmental variation attributed to the differences in altitude. Similarly, in Helianthemum caputfelis (Agullo et al. 2015) and Vigna Caracalla (Etcheverry et al. 2008), visitation rate declined with higher altitude. In the high Andes of central Chile, the visitation rate also declined toward higher altitudinal range (Arroyo et al. 2006). And particularly in the tropics, the differences in rainfall and temperature due to different altitude could be more important than the photoperiod, since these parameters act as limiting factors in these climate regions (da Cruz et al. 2014).

\section{Pollinator diversity}

As well as their abundance, visitor diversity also varied with altitude. In general, the higher and cooler population received fewer visits, but the visitors were higher in diversity (28 families of insects). In contrast, more 
visitation rate was gained in the lower and warmer sites, but with less insect diversity (only 20 families of insects). At all sites, visitor abundance was higher in the rainy season, probably due to the availability of more flowers in this season. For comparison, previous studies in Wanagama (Ratnaningrum and Indrioko 2014) and Watusipat (Baskorowati 2011), both were the ex situ conservation areas in the Middle Zone of Gunung Sewu, recorded visitation by moths, butterflies, wasps, ants, and flies. $S$. album flowers in India were visited by 15 species of insects, in which ants and bees were the main pollinators (Sindhu-Vereendra and Anantha-Padmanabha 1996). While in Western Australia, the most common pollinators in sandals are bees, flies, beetles, ants, butterflies, and wasps (Tamla et al. 2012). Da Silva et al. (2016) compiled studies on the sandals pollination and revealed that sandalwood is largely pollinated by a diverse range of insects including bees (Apidae, Xylocopidae, Anthorphoridae), ants (Formicidae), wasps (Eumeninae, Vespidae, and Sphecidae), flies (Sarcophagidae, Calliphoridae, Muscidae and Syrphidae), and moths and butterflies (Danaidae, Pieridae and Papilionidae). Pollinator study conducted in Gunung Sewu, for the main species of Melaleuca cajuputi, considered Hymenoptera and Lepidoptera as the potential pollinators (Kartikawati et al. 2013).

Sandalwood flowers characterized by very small size (less than $0.5 \mathrm{~cm}$ in diameter), tiny and concealed stigma (less than $2 \mathrm{~mm}$ in length), less nectar and pollen, and weak odor (Arifriana et al. 2017). Sandals floral parts which are tended to attract pollinators are the inner and outer perigonium, mature pollens and nectars. Anthesis was initiated in the early morning at $06: 00$ to $09: 00 \mathrm{~h}$, and anthers dehisced shortly after floral opening, but will exhaust their pollen by 12 to 24 hours. The pollen is sticky, small-grained, present in a very small quantity, and available for rewards at the early stage of anthesis. Nectar is secreted in the basal portion of perianthium, is available at the peak of anthesis 2 to 3 days after, and will be last for 24 to 48 hours (Ratnaningrum and Indrioko 2014). Nectars were within the range of insect visitation at volume of $<500$ $\mu \mathrm{L}$, and the concentration of $10-45 \%$ (Tamla et al. 2012). Sandalwood in Gunung Sewu possessed the continuous flowering pattern, offering nectars and pollen as rewards during both dry and rainy season (Ratnaningrum and Indrioko 2015, 2016).

A flower with very small size, tiny and concealed stigma, less nectar and pollen, and weak odor attracted only lesser visitors in a limited range of size and type. However, small flowers take more advantages from visitor behavior in term of pollen and stigmatic contacts, since any of insects attempting to reach nectar have also contacted the floral sexual organs (Ortigosa and Gomez 2009). However, in the case of big-sized insects, the interaction with small flowers may cause floral disturbances (Machado and Sazima 2008; Borges et al. 2009; da Cruz et al. 2014), as has also reported in this study.

Study with other species having similar floral characteristic to sandals, a small-hermaphroditic heterostylous and self-incompatible Melochia tomentosa
(Malvaceae), reported visitation by 10 species of bees and five butterflies (Machado and Sazima 2008). This perennial shrubby species of the dry, sparse rainfall, semi-arid regions is having very similar characteristics to sandals as it is self-incompatible, outcrosser, and heterostylous. It also flowered twice a year, in the dry and rainy season. Similarly, anthesis in $M$. tomentosa was initiated in the morning at 06:30 to 07:00 h, anthers dehisced shortly after bud opening, and last for several hours. Nectars, in a small volume ( $7 \mu$ Lper flower) at 25 to $30 \%$ of concentration, was secreted through the day until 16:00 h (Machado and Sazima 2008). Our result was also similar to Caesalpinia echinata which was visited by 11 bee species and two butterflies (Borges et al. 2009). Both plant species are native to the Brazilian semi-arid forests. The hermaphroditic protandrous, white, odorless flowers of Heliconia sp in the Brazilian Atlantic tropical forests were visited by Lepidopterans and Hymenopterans (da Cruz et al. 2014).

The altitudinal reduction on pollinators and pollination rate may exist as a consequence of the turnover in the fauna diversity with altitude (Etcheverry et al. 2008; Ortigosa and Gomez 2009; Agullo et al. 2015). Furthermore, this altitudinal reduction is paralleled by an altitudinal turnover in the major pollinator groups. In the higher altitude of temperate regions, the high demanding endothermic hymenopterans were replaced by passively thermoregulating lepidopterans (Agullo et al. 2015) and less-energy demanding dipterans (Ortigosa and Gomez 2009; Agullo et al. 2015), beetles and ants (Ortigosa and Gomez 2009). Both the altitudinal reduction in visitation rate and the replacements of pollinators were considered as the result of lower temperatures and increased cloudiness at the higher elevation, which reducing the insects activities. However, as also reported in this study, the altitudinal role may differ in the warmer, dryer regions such as the arid and tropical climatic zones (Tsaliki and Diekmann 2011; Agullo et al. 2015). In contrast to those of temperate zones, the higher and cooler population in Gunung Sewu was visited more by Dipterans and Hymenopterans, while the warmer and lower sites were dominated more by Lepidopterans and Dipterans. The lower sites experienced fewer visits by Coleopterans and Hemipterans. The presence of each type of floral visitors is distinctive and consistent across the altitudinal gradients. Similarly, in the highland populations of the hermaphroditic protandrous Erysimum nevadense and E. baeticum, the most frequent flower visitors were beetles (Melyridae) and ants (Formicidae). Whereas similar Erysimum grew in lower sites were visited more by bees and butterflies. In addition, flies of Bombyliidae and Syrphidae were present in a very low frequency (Ortigosa and Gomez 2009). In the hermaphroditic self-compatible but outcrosser Vigna caracalla in north-western Argentina, both lower and higher altitude populations were visited by Hymenopterans (Bombus morio, Centris bicolor, Eufriesea mariana and Xylocopa eximia). However, the visitation rate was much lower in the highland population (Etcheverry et al. 2008).

The visitor frequency and efficiency vary with their structures, abundance and feeding behavior, since these 
traits may affect stigmatic contact, pollen load and interplant movement, which in turn ensure pollen transfers. Most of the insect families in this study were considered "rare" and "occasional" as they only made infrequent visits and/or less contact with floral organs. Each of Lepidopteran, as a single family, considered occasional due to their limited quantity. However, in unifying of the whole families, the order of Lepidopterans considered "frequent" and "effective" at all sites, since they were present in frequent numbers (ranged from $21 \%$ to $43 \%$ ), and their feeding behavior ensures the intensive contact to floral sexual organs. This study observed two groups of Lepidopterans, the butterflies and moths groups, visiting sandalwood flowers. Butterflies bore few pollen grains in the smooth feathers of their feet and proboscis. They have sucking-type of mouth which allowed them to enter the flower as close as possible to collect nectars, and hence promote the intensive stigmatic contact and pollen transfer. Butterflies were taking nectars by both hovered or landed on the flowers surface. They made contact with the anthers and stigma using their legs and the ventral portion of the body. They stay for several minutes on the same inflorescence before moving to the other inflorescences and trees. They also observed to move among different flowers across the trees in the distance, hence enhance the probability of cross-pollination. However, their low presence lowered the opportunity of pollen transfer. And as it was rare for visitors, this group was considered "occasional". This was also a case with $M$. tomentosa flowers in which only the bigger butterfly group were "effective", while the smaller ones were "occasional". According to the general rule, butterflies are not effective in tropical areas (Machado and Sazima 2008). Other smaller butterflies were even considered nectar robber (Borges et al. 2009).

Moths, another group of Lepidopterans, presented in the most abundant number, worked intensively in the inflorescences and made many contacts with floral organs. In compared to the butterflies, moth body has more feathers and therefore loaded more pollen. According to their abundance, body structure, and feeding behavior, moths could be considered "effective". However, it is important to underline that the visitation of moths lead to a geitonogamy, since they prefer to stay on the same inflorescence and tree. They work on the same inflorescence for more than an hour before moving to other inflorescences or trees.

The Hymenopterans considered "frequent" and "effective" only at Nglanggeran, probably due to the suitable highland environment and resource availability. This order was also considered "frequent" and "effective" in Wanagama, a lower site which produced more flowers. In this study, a sufficient stigmatic contact and pollen load by Hymenopterans was observed on the feeding behavior of bees. Bees worked effectively while seeking for nectar and pollen, and always contacted the floral reproductive parts of the ventral region of their thorax and abdomen. Their hairy thorax and abdomen, the brush-structured frontfeet, and the basket-like back-feet, all carried the abundant load of pollen. They presented in a fit size to promote an intensive contact with both stigma and anthers, while entering flower to reach for nectars. This diurnal pollinator worked in a group, were moving among flowers and trees within the population, even across the distance to other populations, ensuring the effective cross-pollination in a sufficient number. Similar behavior was also reported for bee pollination in Melochia tomentosa (Machado and Sazima 2008) and Caesalpinia echinata (Borges et al. 2009), both are the species of the Brazilian semi-arid regions; as well as those reported for bee pollination in Melaleuca cajuputi (Kartikawati et al. 2013).

For comparison, previous studies in Wanagama (Ratnaningrum and Indrioko 2014) and Watusipat (Baskorowati 2011) ex-situ conservation areas recorded bees and moths as the most frequent visitors in $S$. album, followed by ants, butterflies, wasps, and flies. In other study, bees visiting both Melochia tomentosa and Caesalpinia echinata belonged to the family Halictidae and Apidae. All of the bee visitors, in spite of the small flower size and morphology in relation to the bees' body size, acted as pollinators in term of their feeding behavior and frequency of visits. However, depending on their abundance, visitation frequency, and the stigmatic and pollen contacts, bees were considered "effective" in Melochia tomentosa (Machado and Sazima 2008) but were "occasional" in Caesalpinia echinata (Borges et al. 2009). The exception was made for Trigona group, which is considered a nectar-robber in both of studies. Nectar or pollen robber is a common finding for Trigona bees (Machado and Sazima 2008; Borges et al. 2009).

All six of bee genera visiting sandalwood flowers (Apidae, Scoliidae, Megachilidae, Xylocopidae, Eumenidae, and Vespidae) began their visits right after anthesis and continued the activity until the end of anthesis. Except for Apidae which stay longer, other bee visits were shorter, only about $5 \mathrm{~s}$ to $10 \mathrm{~s}$, with stigmatic and pollen contacts depending on the bee size. For comparison, in $M$. tomentosa flowers, bees of the genera Centris and Xylocopa, as well as Apidae, began their activities soon after flower opening until the end of anthesis, and have shorter visits in only about 5s. Apis mellifera was the most frequent visitor on $M$. Tomentosa $(60 \%$ of the total of bee visits). Many of bee species foraged at the same time on different flowers within the same tree, were performing sequential visits on numerous flowers, before moving to the other trees. Other bees were acceptable visitors as well, regarding the stigmatic and pollen contacts; however, their presence is less than 20\% (Machado and Sazima 2008).

Working all together, the Dipterans considered "frequent" (ranged from $31.8 \%$ to $35.9 \%$ ) and "effective" at all sites, while both the beetles (Coleopterans) and wasps (Hemipterans) were "rare" and "occasional". Flies and thrips (Dipterans) presented in a most frequent number, worked intensively within the same inflorescences in a certain way which ensured the stigmatic and pollen contact, and were moving among trees within the population. A hairy thorax and abdomen of flies gained more pollen loads. But a small and slimy-surface structure of thrips (Dipterans), beetles (Coleopterans) and wasps (Hemipterans) can only bore a low quantity of pollens. 
Their small size allows them to enter the flower as deep as possible to collect nectars, caused a high stigmatic contact. Unfortunately, the less pollen load resulted in a low pollen transfer onto the stigma. Dipterans presented in a frequent number but the Coleopterans and Hemipterans were less abundant. Wasps, flies, and beetles moved among flowers and trees, hence promote the cross-pollination. In contrary, thrips preferred to stay at the same flower and tree during a long period of feeding. The Cicadellidae of Coleopterans, along with other taxa such as arachnids and grasshoppers, were even considered robbers as they took advantages without made any contacts on floral sexual organs. The arachnids and grasshoppers, which belonged to other order, were even observed to cause floral damages while seeking for rewards.

Ants (Hymenopterans), with a so-tiny body which allow them to reach the deepest space of entire flower parts, were found abundantly almost in a whole day. It was observed to explore nectars deep in the basal portion of the receptacle, walk along the stylus to reach the stigma, or quickly to move among flowers; resulting in a very high stigmatic contact. However, their small size and slimy body surface can only result in low pollen load. They stay in the same inflorescence within the same tree, a behavior which minimized the opportunity for cross-pollination. A larger chance of geitonogamy in beetles and ants pollination was also reported with Erysimum sp in Sierra Nevada (Ortigosa and Gomez 2009), as well as Melaleuca cajuputi in Gunung Sewu (Kartikawati et al. 2013). Beetles and ants, with their small-sized body, may enter the flowers legitimately. However, they prefer to stay in the same tree within a whole day, resulted in the high rate of selfpollination.

According to the large number of visitors of different taxa which visit the flowers (28 species), sandalwood is considered generalistic, a case which was also observed with Conocarpus erectus (27 species), Laguncularia racemosa (12 species) (Nadia and Machado 2014), and Erysimum sp (30 species of 20 families) (Ortigosa and Gomes 2009). The protogyny, small, off-white flowers of $L$. racemosa and $C$. erectus, the two of mangrove species, were visited by flies, wasps, bees, butterflies and diurnal moths. At both mangrove species, visitations were dominated by Dipterans, the fly of Palpada albifrons (Syrphidae). In the brush-type flowers of $C$. erectus, the second most frequent visitors were butterflies (Hesperiidae) and moths (Noctuidae). While in the bowl-type flowers of L. racemosa, the second most frequent visitors were bees (Halictidae and Apidae). Both plant species were also visited by other flies (Sarcophagidae) and wasps in an infrequent visit (Nadia and Machado 2014).

All of the agents were considered diurnal visitor. However, the time range of activity was varied. Most of the families visited flowers before the daytime and reached the peak of activities at 10:00 to 11:00 am, with the exception for the highest altitude population Nglanggeran in which the visitors activity was still recorded until 05:00 pm. In general, moths found in the earliest morning at 05:00 am and tended to have a longer interval of activity since their presence was still recorded until 04:00 pm. Bees and flies observed 1 hour later at 07:00 am to 02:00 pm. Wasps, beetles, and flies found later at 08:00 am and finished their activity at 03:00 pm. The latest was butterflies which have just found after 09:00 am and disappeared at 03:00 pm. While, ants presence were observed within the same tree the whole day through.

For comparison, insects visitation in Watusipat was higher in the morning in the following sequence: moths (06:00 to $08: 00)$, bees $(07: 00$ to $10: 00)$, wasps $(08: 00$ to 10:00), and butterflies (09:00 to 12:00) (Baskorowati 2011). In addition, ants and flies were observed at the same inflorescences and trees throughout the day (Ratnaningrum and Indrioko 2014). Similar results were reported with sandalwood in India, where pollination activities peaked only before daytime in the warmer site, but prolonged until afternoon in the cooler area (Sindhu-Vereendra and Anantha-Padmanabha 1996). This may explain the occurrence of most diverse visitors in a highland population, Nglanggeran. The Highland environmental weather might provide longer period of rewards availability (Warburton et al. 2000), more pleasant environment for feeding activities, and more suitable habitat for wider insect diversity (Tsaliki and Diekmann 2011). Similarly, in the highland populations of the hermaphroditic protandrous Erysimum nevadense and E. baeticum, the most frequent flower visitors were beetles (Melyridae) and ants (Formicidae). While in the lower sites, visitation was dominated more by bees and butterflies. In addition, flies of Bombyliidae and Syrphidae were present in a very low frequency, less than 5\%. Most taxa were considered generalist (Ortigosa and Gomez 2009). However, the contradictory result was reported in several temperate regions where dryer and warmer weather were more suitable for pollinator activity (Weber and Kolb 2013). In another study, the hermaphroditic protandrous, white, odorless flowers of Heliconia sp. in the Brazilian Atlantic tropical forests were visited by humming birds, Lepidopterans, and Hymenopterans (da Cruz et al. 2014). Lepidopterans conducted their visits from 07:00 a.m. to 02:00 p.m., while the Hymenopterans of Trigona sp have just started at 10:00 a.m. The peak of visits for all visitors was between 07:00 a.m. to 08:00 a.m. The most frequent visitor was the hummingbirds, while the butterflies were considered occasional, and the bees were robbers (da Cruz et al. 2014). In L. racemosa, the peak visitor activity was from 07:00 a.m. to 02:00 p.m. Flies, moths and wasps visited flowers of the same tree in a long period, increase the rate of geitonogamy (Nadia and Machado 2014).

\section{The effects of floral and pollination traits on the reproductive outputs}

In this study, the reproductive outputs differed significantly among sites but were similar between two seasons. The variation in flowers abundance and pollination rate may contribute to the differences in reproductive outputs among sites. This study predicted that flowering and pollination affect reproductive outputs, and therefore the populations which produce more flowers will gain more visitors and performed more seed sets, seed viability, and seedling survival. However, some of the 
results showed a strong departure from this prediction. Flowers abundance strongly affected pollination effectiveness and reproductive success, but less correlated to the seed viability and seedling survival. And surprisingly, both flowers abundance and pollination rate showed negative trend line in any of regression analysis correlated to the reproductive parameters. It implied that the populations might produce more flowers and flowering trees, and hence gain more pollinators; however, the reproductive outputs were significantly lower.

The more clonalized populations reported being more inbreeder. It implied that the effects of flowering and pollination to the mating systems might vary with the composition of parents, with regard to their clonality level and genetic composition. Parents might produce more flowers and gain more pollinators, but exhibit a very low outcrossing rate, as was a case for Petir and Bejiharjo. In both of highly clonalized populations, most of the flowering trees were derived from root suckers which shared the same parent, and therefore were genotypically identic (Indrioko and Ratnaningrum 2015a; Arifriana et al. 2017). Even when flowers and pollinators were abundant, the geitonogamy dominated mating within these clonalized populations resulted in the high selfing rate (Ratnaningrum et al. 2015, 2016).

S. album is predominantly outbreeder (SindhuVereendra and Anantha-Padmanabha 1996; Ratnaningrum and Indrioko 2014). Studies reported high pollen fertility $(88.4 \%)$ in S. album in India (Sindhu-Vereendra and Anantha-Padmanabha 1996) and high rate of pollination effectiveness (10 to 40\%) in S. album in Java island (Ratnaningrum and Indrioko 2014), but a very low seed sets indicated the genotypic barriers to embryo development, probably due to the post-zygotic selfincompatibility mechanism (Sindhu-Vereendra and Anantha-Padmanabha 1996; Warburton et al. 2000; Rughkla et al. 2006; Tamla et al. 2012). Selfincompatibility, which may occur at both pre- and postzygotic levels, have arisen in evolution as a way of preventing self-pollination events (Barrett 2011; Wilmer 2012). Hence, reproductive success may be reduced in the self-incompatible, outbreeder species which less flowered, having small populations, or highly clonalized (Warburton et al. 2000; Lhuillier et al. 2006; Provan et al. 2008; Indrioko and Ratnaningrum 2015a). Furthermore, the selfincompatible, outbreeder species are highly dependent on pollinators for their sexual reproduction (Agullo et al. 2015); hence the risk of reduced reproductive success is higher in such populations (Provan et al. 2008). Similar result was also reported with the self-incompatible, outbreeder Genista anglica in which the number of seeds decreased with the increase of selfing, and the authors considered the constraints induced by self-incompatibility and reduced cross-pollination to be a reasonable explanation for these findings (Tsaliki and Diekmann 2011).

It is generally expected that the mating systems, which affect the reproductive outputs, were influenced by key floral traits such as the number of flowers and flowering trees (Herlihy and Eckert 2007; Arroyo et al. 2006; Barrett
2011; Wilmer 2012; Ratnaningrum et al. 2015). For example, in a small, hermaphroditic protandrous and highly self-incompatible Phyteuma spicatum in central Europe, reproductive success was affected more by the flowers and pollinator abundance, and therefore, the reproductive fitness was higher in species with abundant flowers (Weber and Kolb 2013). However, in contrast, floral abundances should also have opposing effects on the mating system, by increasing geitonogamous selfing, as has reported in this study. In the case of sandalwood, mass flowering has an advantage in attracting pollinators, but may also increase the level of self-pollination. This may explain the significant reduction in seed viability and seedling survival at the abundantly flowered populations, particularly those undergo heavy clonality, which might be considered as the effect of inbreeding depression. It was also the case with the self-incompatible Aquilegia canadiensis (Herlihy and Eckert 2007), a self-compatible endangered shrub Helianthemum caput-felis endemic to Mediterranean basin (Agullo et al. 2015), and Caesalpinia echinata (Borges et al. 2009). All these three species flowered abundantly, but geitonogamy reduced fruit sets and survivals, particularly in the small and/or clonalized populations.

The behavior of pollinator may affect the mating systems and reproductive outputs of plants in two ways: insufficient pollination service or low-quality pollen transfer (Machado and Sazima 2008; Nadia and Machado 2014). The geitonogamy may have pre- and post-zygotic deleterious effects, such as pollen discount, stigma clogging, inbreeding depression, and even genetic extinction (Provan et al. 2008; Ortigosa and Gomez 2009). In this study, a larger possibility of self-pollination was observed in moths, thrips, and ants pollination. Actually, moths can be considered effective according to their abundance, body structure, and feeding behavior. However, their visitation behavior, as well as those observed in thrips and ants, lead to a geitonogamy, since they prefer to stay on the same inflorescence and tree for more than an hour. This was also reported with Erysimum sp in the Sierra Nevada (Ortigosa and Gomez 2009) in which beetles and ants prefer to stay at the same tree within a whole day, resulted in the high rate of self-pollination. In L. racemosa, flies, moths, and wasps visited flowers of the same tree in a long period, hence increase the rate of geitonogamy (Nadia and Machado 2014). A similar case was also reported with the visitation of several wasps and moths on Melaleuca cajuputi (Kartikawati et al. 2013).

Significant reduction in seed viability and seedling survival at the abundantly flowered populations might be considered as the effect of inbreeding depression (Culley et al. 1999; Dudash and Fenster 2001; Ratnaningrum et al. 2015). Inbreeding depression in this study occurred at various stages of development, which can be earlier or later, depending on the time intervals in which populations were subjected to this inbreeding condition. The evidence of late-acting inbreeding depression was observed in population which has been exposed to such a condition which favor inbreeding for a relatively longer period, and therefore seemed to be adapted to its new mating systems. Petir has been exposed to a clonality condition, and 
therefore has been dominated by self-mating system, since the 1970s' period (Indrioko and Ratnaningrum 2015a; Arifriana et al. 2017). For Petir, the effect of inbreeding depression might have only occurred at the very late phase. This highly clonalized, lower parental heterozygosity and higher selfing rate population, was surprisingly produced more abundant and viable seeds, indicating the absence of inbreeding depression at the pollination and fertilization level. The germination rate was also relatively high. However, a very low survival was observed in the three months old seedlings, indicated the late-acting inbreeding depression. In contrast, inbreeding depression was expressed at the early phase of development for the population which experienced ongoing disturbances for a relatively shorter period. Low reproductive outputs in Bejiharjo were considered to be the effect of the earlyacting inbreeding depression. In Bejiharjo, the parental heterozygosity was previously moderate $\left(\mathrm{H}_{\mathrm{o}} 0.202\right)$ in the past, and therefore there was no impact of founder effects (Indrioko and Ratnaningrum 2015a). Later at 1980's the heavy exploitation began, up to the big riots in 1998 's, followed by habitat fragmentation due to eco-tourisms and urban activities since 2000's. These events resulted in very intensive clonality, which in turn significantly increased self-mating and reduced genetic diversity. In such a case, this relatively short time period was insufficient enough to deal with the new mating processes under a new population structure. Hence, Bejiharjo responded differently in responding the condition which favored inbreeding. Differed to Petir which suffered from inbreeding depression at the earlier phases, the Bejiharjo population experienced a very high inbreeding depression at a very early phase, resulting in a very low number of mature seeds, with $0 \%$ germination rate.

The high inbreeding depression under clonalized condition was also found in many sandals populations (Warburton et al. 2000; Lhuillier et al. 2006; Ratnaningrum et al. 2015), as well as those observed in other species with similar mating system, i.e. the hermaphroditic, protandrous and highly outcrosser Silene virginica in North America (Dudash and Fenster 2001), a self-compatible hermaphroditic Schiedea membranacea in Hawaiian islands (Culley et al. 1999), and a hermaphroditic outcrosser Melaleuca cajuputi in Gunung Sewu (Kartikawati et al. 2013). In the other hand, the success of reproductive at populations which have been subjected to inbreeding for a long time period could be seen as a result of pre-adapted breeding systems, as reported for $C$. euphrasioides in the highland of Andes, Chile (Arroyo et al. 2006), Santalum spicatum in western Australia (Byrne et al. 2003) and S. australocaledonium in New Caledonia (Bottin et al. 2007). Inbreeding depression in such preadapted populations, if any, might be expressed at the later developmental phase, such as seedlings or saplings level (Indrioko and Ratnaningrum 2015a, 2015b).

In conclusion, the flowers abundance and pollination rate differed significantly between seasons but were similar among sites. More flowers and visits were achieved in the rainy season at all sites. However, the reproductive outputs were much lower due to the high abortion of flowers and fruits. The reproductive outputs differed significantly among sites, but were similar between seasons. Differences in reproductive outputs among sites were not affected by the flowering or pollination, but more by the differences in parental clonality, genetic diversity, and mating systems. In more clonalized, low heterozygosity and highly inbreeder populations, more flowers gained more visits but increase the selfing rate and inbreeding depression. Hence the reproductive outputs were much lower. Visitation rate is less correlated to the flowers abundance per individual, but more affected by the population size with regard to the proportion of flowering trees in populations. The higher altitude population, with cooler and wetter $\mathrm{Am}$ climatic type, visited more by Dipterans $(31.8 \%$ to $32.6 \%)$ and Hymenopterans $(28.2 \%$ to $30 \%)$. Whereas the warmer and lower sites under $A w$ climatic type were dominated by Lepidopterans $(37.2 \%$ to $43 \%)$ and Dipterans $(32.9 \%$ to $38.2 \%)$. The lower sites experienced fewer visits by Coleopterans (ranged from $1.9 \%$ to $5.8 \%$ ) and Hemipterans $(3.4 \%$ to $4.3 \%)$. Both orders made more visits to the highland site $(8.3 \%$ for Coleopterans and $7.9 \%$ for Hemipterans). At all sites, the rainy season gained more visits, along with the availability of more rewards. The higher population received fewer visits, but the visitors were more diverse (28 families). In contrast, more visitation rate was gained in the lower sites, but with less diversity (20 families). The Byturidae, Tenebrionidae, and Coccinellidae (Coleopterans), Pipunculidae and Stratiomydae (Dipterans), Scoliidae and Megachilidae (Hymenopterans), and Phyrrocidae, Scutelleridae and Cicadellidae (Hemipterans), were found only in the highland population. In contrary, the Platasipidae (Hemipterans) were found only at the lowland sites. The Cossidae family, which belongs to the moths group of Lepidopterans, was appeared only in the lowland sites in the rainy season. Most of insect families were "rare" and "occasional" at all sites. However, when pooled altogether, the Lepidopterans and Dipterans were "frequent" and "effective". The Hymenopterans were "frequent" and "effective" at Nglanggeran and Wanagama. The Cicadellidae of Coleopterans, along with arachnids and grasshoppers, were robbers. All of agents were diurnal visitors, however, the time range of activity was varied. All of agent activities peaked before daytime.

\section{ACKNOWLEDGEMENTS}

These results are a part of Yeni W.N. Ratnaningrum's Ph.D. research on sandalwood genetic conservation and improvement; which is supported by the grant of Hibah BPPS year 2012-2015, and the grant of Hibah Penelitian Disertasi Doktor year 2017, by Direktorat Jenderal Pendidikan Tinggi, Kementerian Pendidikan dan Kebudayaan Indonesia. The seed testing was conducted in the Forest Seed Science and Technology Laboratory of Silviculture Department, Universitas Gadjah Mada in Yogyakarta, Indonesia, and we would like to express our gratitude to Widaryanti W. Winarni as the head of the laboratory. Many thanks go to Harno for laboratory works, 
and Jito for green house works. Our gratitude also goes to Andiyanto (Nglanggeran), Sunar (Bejiharjo), Kustini (Bleberan), Tukiyat (Wanagama), and Suparsono (Petir) for field assistances.

\section{REFERENCES}

Agullo JC, Perez-Banon C, Crespo MB, Juan A. 2015. Puzzling out the reproductive biology of the endangered cat's head rockrose (Helianthemum caput-felis, Cistaceae). Flora 217: 75-81.

Arifriana R, Indrioko S, Syahbudin A. 2017. Variasi cendana (Santalum album Linn.) berdasarkan morfologi daun dan bunga di Desa Petir, Rongkop, Gunungkidul._Jurnal Ilmiah Kehutanan 11: 97-108. [Indonesian]

Arroyo MTK, Muñoz MS, Henríquez C, Till-Bottraud I, Pérez F. 2006. Erratic pollination, high selfing levels and their correlates and consequences in an altitudinally widespread above-tree-line species in the high Andes of Chile. Acta Oecologica 30: 248-257.

Barrett SCH. 2011. Why reproductive systems matter for the invasion biology of plants. In: Richardson DM (ed.). Fifty Years of Invasion Ecology. Blackwell Publishing Ltd., New Jersey.

Baskorowati L. 2011. Flowering intensity and flower visitors of Santalum album L. at ex-situ conservation plot, Watusipat, Gunung Kidul, Yogyakarta. J For Res 8: 130-143.

Borges LA, Sobrinho MS, Lopes AV. 2009. Phenology, pollination and breeding system of the threatened tree Caesalpinia echinata Lam. (Fabaceae), and a review of studies on the reproductive biology in the genus. Flora 204 (2): 111-130.

Bottin L, Tassin J, Nasi R, Bouvet J. 2007. Molecular, quantitative and abiotic variables for the delineation of evolutionary significant units: case of sandalwood (Santalum austrocaledonicum Vieillard) in New Caledonia. Conserv Genet. 8: 99-109.

Byrne M, MacDonald B, Broadhurst L, Brand J. 2003. Regional genetic differentiation in Western Australian sandalwood (Santalum spicatum) as revealed by nuclear RFLP analysis. Theor Appl Genet 107: 1208-1214.

Culley TM, Weller SG, Sakal AK, Rankin AE. 1999. Inbreeding depression and selfing rates in a self-compatible, hermaphroditic species, Scheidea membranacea (Caryophyllaceae). Am J Bot 86 (7): 980-987.

da Cruz DD, e Silva MC, de Albuquerque NSL. 2014. Floral syndrome, resources and pollinator guilds: a case study of Heliconia psittacorum L.f. (Heliconiaceae). Iheringia Serie Botanica 69 (2): 303-312.

da Silva JAT, Page T, Zhang X, Kher MM, Nataraj M, Soner D, Ma G. 2016. Sandalwood: basic biology, tissue culture, and genetic transformation. Planta 243: 847-887.

Dani KGS, Ravikumar P, Kumar RP, Kush A. 2011. Genetic variation within and among small isolated populations of Santalum album. Biologia Plantarum 55 (2): 323-326.

Office of Forestry Yogyakarta Province [Dinas Kehutanan Provinsi Yogyakarta]. 2015. Laporan Inventory Tegakan Hutan di Kabupaten Gunungkidul. Bagian Perencanaan dan Pemetaan Hutan. KPHP Dinas Kehutanan Daerah Istimewa Yogyakarta. [Indonesian]

Dudash MR, Fenster CB. 2001. The role of breeding system and inbreeding depression in the maintenance of an outcrossing mating strategy in Silene virginica (Caryophyllaceae). Am J Bot 88 (11): 1953-1959.

Etcheverry AV, Aleman MM, Fleming TF. 2008. Flower morphology, pollination biology and mating system of the complex flower of Vigna caracalla (Fabaceae: Papillionidae). Ann Bot 102 (3): 305-316.

Haryono E, Suratman. 2010. Significant features of Gunung Sewu Karst as geopark site. In: Aziz RA (ed.). Proceeding on 4th International UNESCO Conference on Geopark. Langkawi, 12-15 April 2010.

Herawan T, Na'iem M, Indrioko S, Indrianto A. 2014. Somatic embryogenesis of Sandalwood (Santalum album L.). Indo J Biotech 19 (2): $168-175$.

Herlihy CR, Eckert CG. 2007. Evolutionary analysis of a key floral trait in Aquilegia canadensis (Ranunculaceae): genetic variation in herkogamy and its effect on the mating system. Evolution 61 (7): 1661-1674.

Indrioko S, Ratnaningrum YWN. 2015a. Habitat loss caused clonality, genetic diversity reduction and reproductive failure in Santalum album, an endangered endemic species of Indonesia. Procedia Environ Sci 5: 613-620.

Indrioko S , Ratnaningrum YWN. 2015b. Pengaruh Degradasi Habitat terhadap Dinamika Genetik dan Kemampuan Reproduksi Cendana pada Beberapa Populasi di Nusa Tenggara Timur. Final Report on DPP Research Grant. Universitas Gadjah Mada, Yogyakarta. [Indonesian]

IUCN. 2009. IUCN Red List Categories And Criteria: Version 3.1. IUCN Species Survival Commission. International Union for Conservation of Nature and Natural Resources. Glad, Switzerland, and Cambridge, UK.

Kartikawati NK, Naiem M, Hardiyanto EB, Rimbawanto A. 2013. Improvement of seed orchard management based on mating system of cajuput trees. Indo J Biotech 18 (1): 26-35.

Lhuillier E, Butaud JF, Bouvet JM. 2006. Extensive clonality and strong differentiation in the Insular Pacific tree Santalum insulare: implications for its conservation. Ann Bot 98: 1061-1072.

Machado IC, Sazima M. 2008. Pollination and breeding system of Melochia tomentosa L. (Malvaceae), a keystone floral resource in the Brazilian Caatinga. Flora 203 (6): 484-490.

Nadia TL, Machado IC. 2014. Interpopulation variation in the sexual and pollination systems of two Combretaceae species in Brazilian mangroves. Aquat Bot 114: 35-41.

Ortigosa AL, Gomez JM. 2009. Differences in the diversity and composition of the pollinator assemblage of two co-flowering congeneric alpine wallflowers, Erysimum nevadense and E. baeticum. Flora 205 (4): 266-275.

Owens JN, Sornsathapornkul P, Thangmitcharoen S. 2001. Studying Flowering and Seed Ontogeny in Tropical Forest Trees. ASEANCanada Forest Tree Seed Centre. Muak-lek, Saraburi.

Provan J, Beatty GE, Hunter AM, McDonald RA, McLaughlin E, Preston SJ, Wilson S. 2008. Restricted gene flow in fragmented population of a wind-pollinated tree. Conserv Genet 9: 1521-1532.

Rao MN, Ganeshaiah KN, Shaanker RU. 2007. Assessing threats and mapping sandal resources to identify genetic 'hot-spot' for in-situ conservation in peninsular India. Conserv Genet 8: 925-935.

Ratnaningrum YWN, Indrioko S, Faridah E, Syahbudin A. 2016. Flowering and seed production of sandalwood (Santalum album Linn., Santalaceae) along environmental gradients in Gunung Sewu Geopark, Indonesia. Nusantara Biosci 8 (2): 180-191.

Ratnaningrum YWN, Indrioko S, Faridah E, Syahbudin A. 2015. The effects of population size on genetic parameters and mating system of sandalwood in Gunung Sewu, Indonesia. Indon J Biotech 20 (2): 182201.

Ratnaningrum YWN, Indrioko S. 2015. Response of flowering and seed production of sandalwood (Santalum album linn., Santalaceae) to climate changes. Procedia Environ Sci 5: 665-675.

Ratnaningrum YWN, Indrioko S. 2014. Variation on genotypes and flowering characters affecting pollination mechanisms of sandalwood (Santalum album Linn., Santalaceae) planted on ex-situ gene conservation in Yogyakarta, Indonesia. Eur J For Res 6: 167-179.

Richardson AD, Keenan TF, Migliavacca M, Ryua Y, Sonnentaga O, Toomey M. 2013. Climate change, phenology, and phenological control of vegetation feedbacks to the climate system. Agric For Meteor 169: 156-173.

Rughkla A, McComb JA, Jones MGK. 2006. Intra-and inter specific pollination of Santalum spicatum and S. album. Aust J Bot 45 (6): 1083-1095.

Sindhu-Veerendra HCS, Anantha-Padmanabha HSA. 1996. The breeding system in Sandal (Santalum album L.). Silvae Genetica 45 (4): 188190.

Tamla HT, Cornelius JP, Page T. 2012. Reproductive biology of three commercially valuable Santalum species: development of flowers and inflorescences, breeding systems, and interspecific crossability. Euphytica 184: 323-333.

Tsaliki M, Diekmann M. 2011. Population size, pollination and reproductive success in two endangered Genista species. Flora 206 (3): $246-250$

Warburton CL, James EA, Fripp YJ, Trueman SJ, Wallace HM. 2000. Clonality and sexual reproductive failure in remnant populations of Santalum lanceolatum (Santalaceae). Biol Conserv 96 (1): 45-54.

Weber A, Kolb A. 2013. Population size, pollination and phenotypic trait selection in Phyteuma spicatum. Acta Oecologica 47: 46-51.

Wilmer P. 2012. Ecology: Pollinator-plant synchrony tested by climate change. Curr Biol 22 (4): R131-R132. 